\title{
AGE CHANGES IN ARTICULAR CARTILAGE OF RABBITS
}

\author{
C. H. BARNETT, W. COCHRANE, AND A. J. PALFREY \\ St. Thomas's Hospital Medical School, London
}

The appearance under the electron microscope of articular cartilage taken from the distal end of the femur has already been described for rabbits ranging in age from 62 to 74 days (Davies, Barnett, Cochrane, and Palfrey, 1962). It was found convenient to divide the cartilage, the total thickness of which ranged from 150 to $450 \mu$, into four zones.

(i) The Superficial Zone.-This contains flattened cells exhibiting paired cytomembranes, mitochondria, and other organelles, but showing no signs of degeneration. They are separated from the extremely smooth surface of the cartilage by a cell-free region 2 to $3 \mu$ thick. The matrix throughout this zone contains fine fibres from 80 to $250 \AA$ in diameter.

(ii) The Upper Middle Zone.-This contains rounded cells with branching irregular processes, often arranged in pairs. In addition to cytomembranes and mitochondria, many cells exhibit pinocytotic vesicles and large Golgi vacuoles, some of which open at the cell surface. The matrix immediately around each cell or between pairs contains fine fibres; the interfibrillar matrix between pairs often shows high electron density. Further from the cell the fibres of the general matrix are coarser (diameter up to $550 \AA$ ) and some display cross-striations with a periodicity of about $400 \AA$, though fibres are rarely cut in longitudinal section.

(iii) The Lower Middle Zone.-This zone is thick and the cells are in groups of three or four, each containing prominent cytomembrane systems with electron-dense material between pairs of membranes. A few cells exhibit signs of degeneration, indicated by breaking of the cytomembranes, loss of the cell membrane, and dispersal of organelle remnants amid the surrounding matrix. In other cells there is great distension of Golgi vacuoles; these discharge a granular material into "moats" that form around the degenerating cell, which is reduced to a branching spidery structure. The fine fibres are again present around and between cells; the fibres of the general matrix in this zone may be as much as $700 \AA$ thick and have the periodicity of mature collagen.

(iv) The Deep Zone.-This contains cells that are mostly degenerate. They are often arranged in columns perpendicular to the surface of the cartilage. The matrix fibres are indistinct but, in some, cross-striations at intervals of about $650 \AA$ are visible, often with interperiod banding. Calcification begins as scattered crystals of apatite amid the coarse fibres of the general matrix; later these aggregate in the form of rosettes.

In this investigation, specimens of articular cartilage from older rabbits have been examined to determine the changes which occur with increasing age.

\section{Material and Methods}

The lower articular surface of the femur has been studied in nine adult rabbits, using similar methods of fixation and staining to those reported in the previous investigation. The ages of the rabbits were 9 months, 1 year 2 months, $2 \frac{1}{2}$ years, 3 years, 3 years 4 months, 4 years, $4 \frac{1}{2}$ years, 5 years, and $6 \frac{1}{2}$ years. A few of the sections for electron microscopy were cut by means of a diamond knife but the majority were cut by glass knives.

In addition, $1 \mu$ araldite sections were examined by the light microscope after staining by the Azur II-methylene blue method of Richardson, Jarett, and Finke (1960). Comparable blocks of tissue were embedded in paraffin wax, sectioned at $10 \mu$, and stained with haematoxylin and eosin. These were compared with similar sections from rabbits aged $2 \frac{1}{2}$ years.

\section{Results}

\section{Light Microscopy}

The cell density of articular cartilage is reduced from about 16 cells per $100 \mu^{2}$ in young rabbits to about 7 per $100 \mu^{2}$ in older animals, counted in sections $10 \mu$ thick cut perpendicular to the surface (Fig. $1 a, b$, overleaf). The total thickness of the cartilage is approximately equal in the two groups. The surface is rougher in older specimens. The few cells near the surface have rounded nuclei; the matrix around these cells lacks the eosinophilic staining seen in young specimens. 


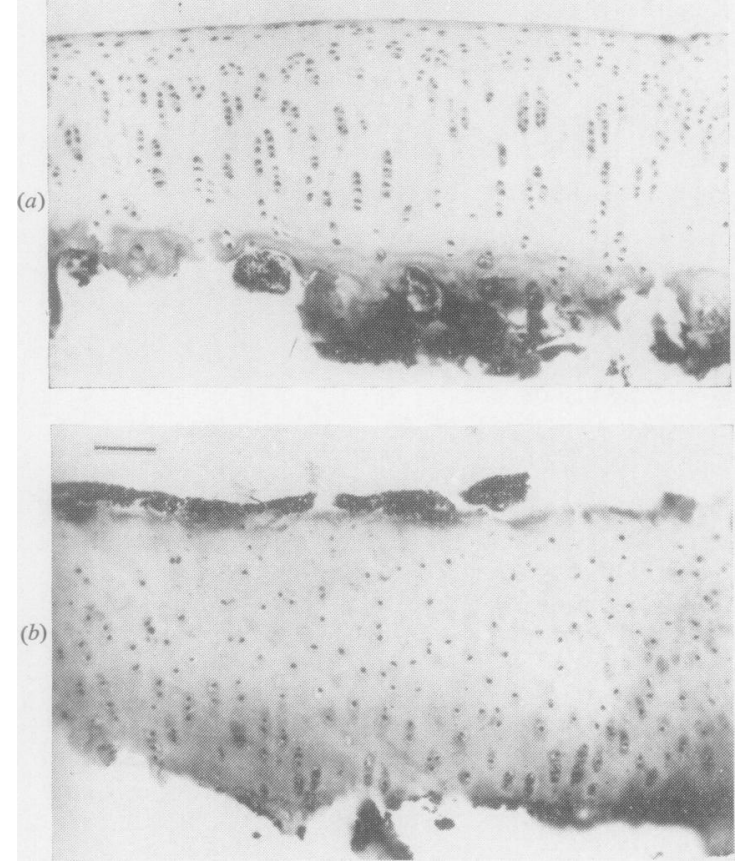

Fig. 1.-Vertical sections through articular cartilage from distal end of rabbit femur. (a) Age 2 months; (b) Age 3 years 4 months. Stained with haematoxylin and eosin $(\times 60)$. Scale marker represents $100 \mu$. (Courtesy of Dr. R. A. Stockwell.)
In older cartilage the cells of the middle zone are generally isolated and many stain imperfectly; in certain cells the nuclei show deep fissures. Enlarged lacunae are uncommon around cells of the middle zone, though these were seen in the younger material.

\section{Electron Microscopy}

Superficial Zone.-The surface of the femoral articular cartilage is less smooth than in young animals, though there is considerable variation from one part of the surface to another and from animal to animal within the same age group. Commonly, regular undulations of the surface are seen. The distance from crest to crest is 1.5 to $2 \mu$ and the perpendicular depth from crest to trough is about $0 \cdot 3 \mu$ (Fig. $2 a$ ). In some specimens the undulations are less regular and sharp prominences to a height of $0 \cdot 8 \mu$ and fissures to a depth of $1 \cdot 3 \mu$ have been observed (Fig. $2 b$, opposite).

At the surface there is a narrow zone, 0.2 to $0 \cdot 3 \mu$ 윽 in thickness, that contains few fibres; this represents the lamina splendens of light microscopy. The cell- $z$ free region beneath the surface is considerably deeper than in young rabbits. It commonly exceeds $10 \mu$, though a few remnants of flattened cells and an occasional rounded cell may be found. The fibres are approximately $160 \AA$ thick; a few shop cross-banding with a periodicity of about 200

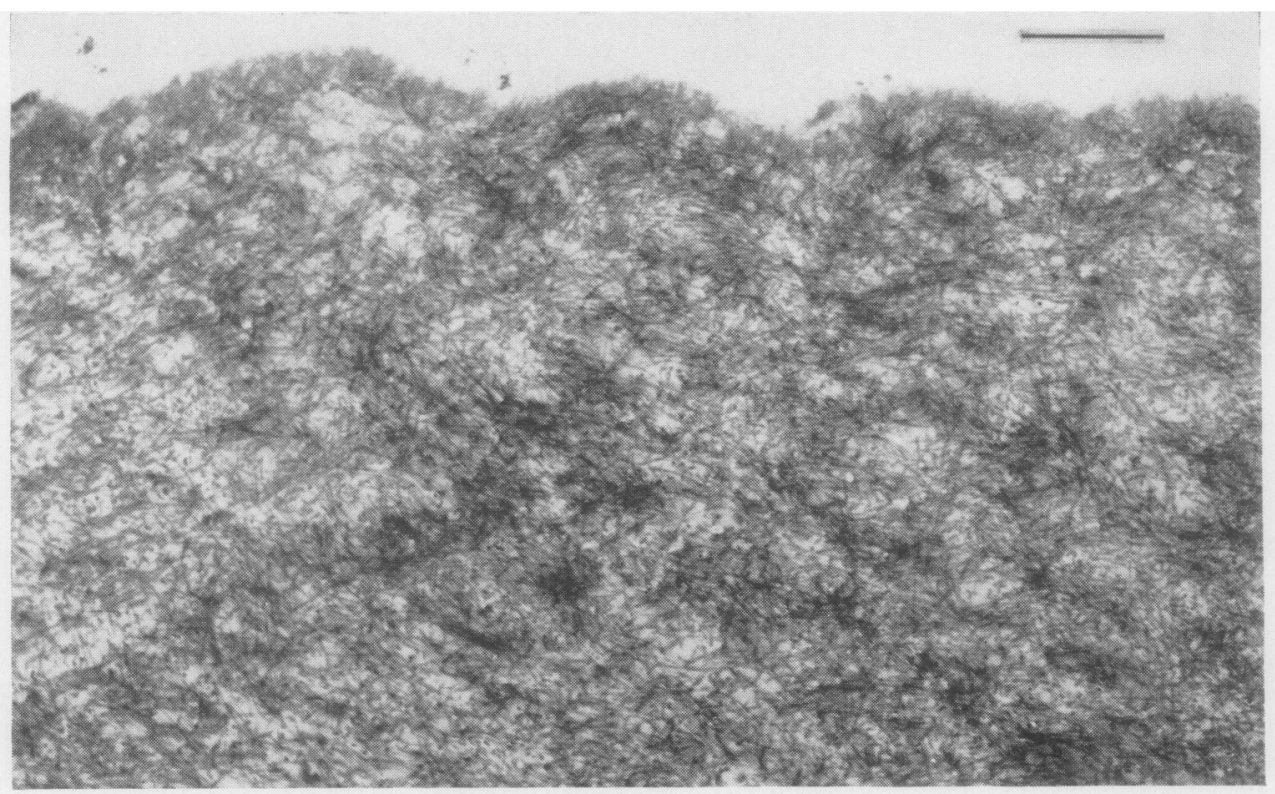

Fig. 2.-Sections through superficial zone of articular cartilage from rabbit aged 1 year 2 months. (a) Undulating surface and cell-free region beneath. Stained with uranyl acetate $(\times 15,000)$. In this and all subsequent figures except $7(b)$ the scale marker represents $1 \mu$. 


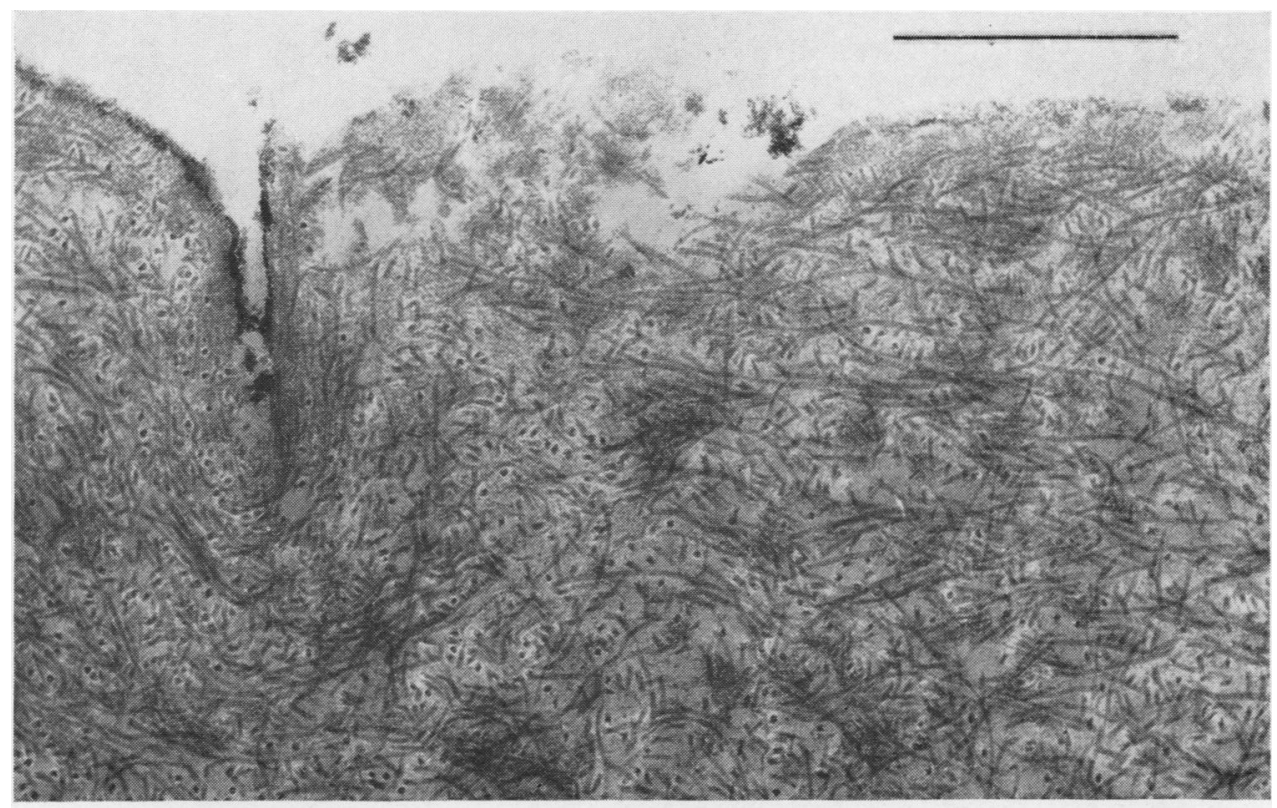

Fig. 2(b).-Irregular surface with fissure. Stained with uranyl acetate $(\times 29,000)$.

Middle Zone.-The cartilage deep to the cell-free zone resembles that of the middle zone in young animals, though it is not possible to distinguish upper and lower parts. Its total thickness is 150 to $300 \mu$. Most of the cells are rounded with irregular surface membranes (Fig. 3, overleaf). They exhibit mitochondria, Golgi vacuoles, pinocytotic vesicles, and occasional fat globules.

There are several features not visible in young cartilage. Most cells are solitary but occasionally they occur in pairs; one of the pair is often poorly stained and has a granular, vacuolated cytoplasm with indistinct organelles (Fig. 4, overleaf).

The nucleus is often indented, horseshoe-shaped or almost completely divided into two or more lobes (Fig. 5a, $b$, overleaf).

No corresponding indentation of the cell membrane has been observed. Bundles of filaments are often seen in the cytoplasm, especially around the nucleus. These are seen cut both longitudinally and transversely (Fig. 6, overleaf).

The filaments have a diameter of 90 to $100 \AA$ and in places they appear irregularly beaded. Granular cytomembranes are seldom conspicuous and when visible the pairs enclose material of low electron density.

In the matrix near to solitary healthy cells it is common to observe numerous irregular bodies massed together. These masses may occupy an area as large as a normal cell and include bodies resembling mitochondria, short lengths of cytomembranes, and other organelles (Fig. $7 a$, overleaf) They lack a limiting membrane and no nucleus can be identified. Other masses are smaller and consist largely of irregular bodies that are seen under high magnification to consist of whorled pairs of nongranular membranes (Fig. $7 b$, overleaf). Each membrane is 20 to $25 \AA$ thick, separated from its partner by an electron-translucent interval of about $30 \AA$. In other parts of the matrix small clusters of these "myelin bodies", together with irregular electrondense granules lie interspersed among fibres (Fig. $7 c$, overleaf).

The matrix in the immediate vicinity of the cells contains fine fibres that are more or less uniform, about $100 \AA$ in diameter. Many are cut longitudinally in lengths of $1 \mu$ or more. Similar fibres are present between pairs of cells. They are found also between the granular masses described above and the adjacent healthy cell. The interfibrillar matrix between pairs of cells does not show the high electron density observed in young cartilage.

In the general matrix of the middle zone the fibres are often cut longitudinally for considerable distances $-0.8 \mu$ or more. Most have a diameter of 750-900 $\AA$, cross-banded with a periodicity of about $650 \AA$, but here and there are found very 


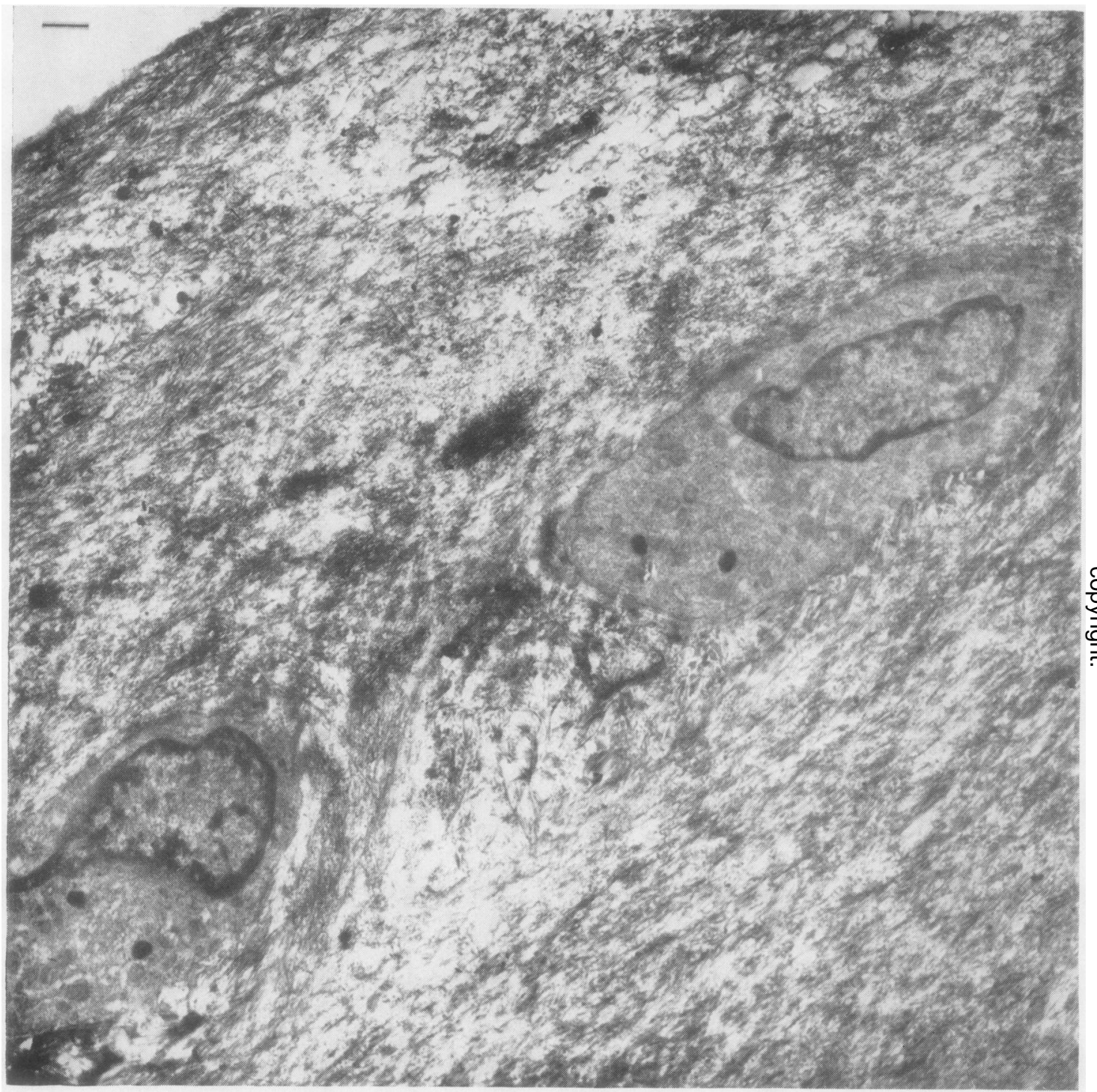

Fig. 3.-Superficial part of cartilage from rabbit aged 3 years, showing surface (top left), wide cell-free zone, and solitary cells in superficial layer. Stained with uranyl acetate $(\times 6,000)$. 


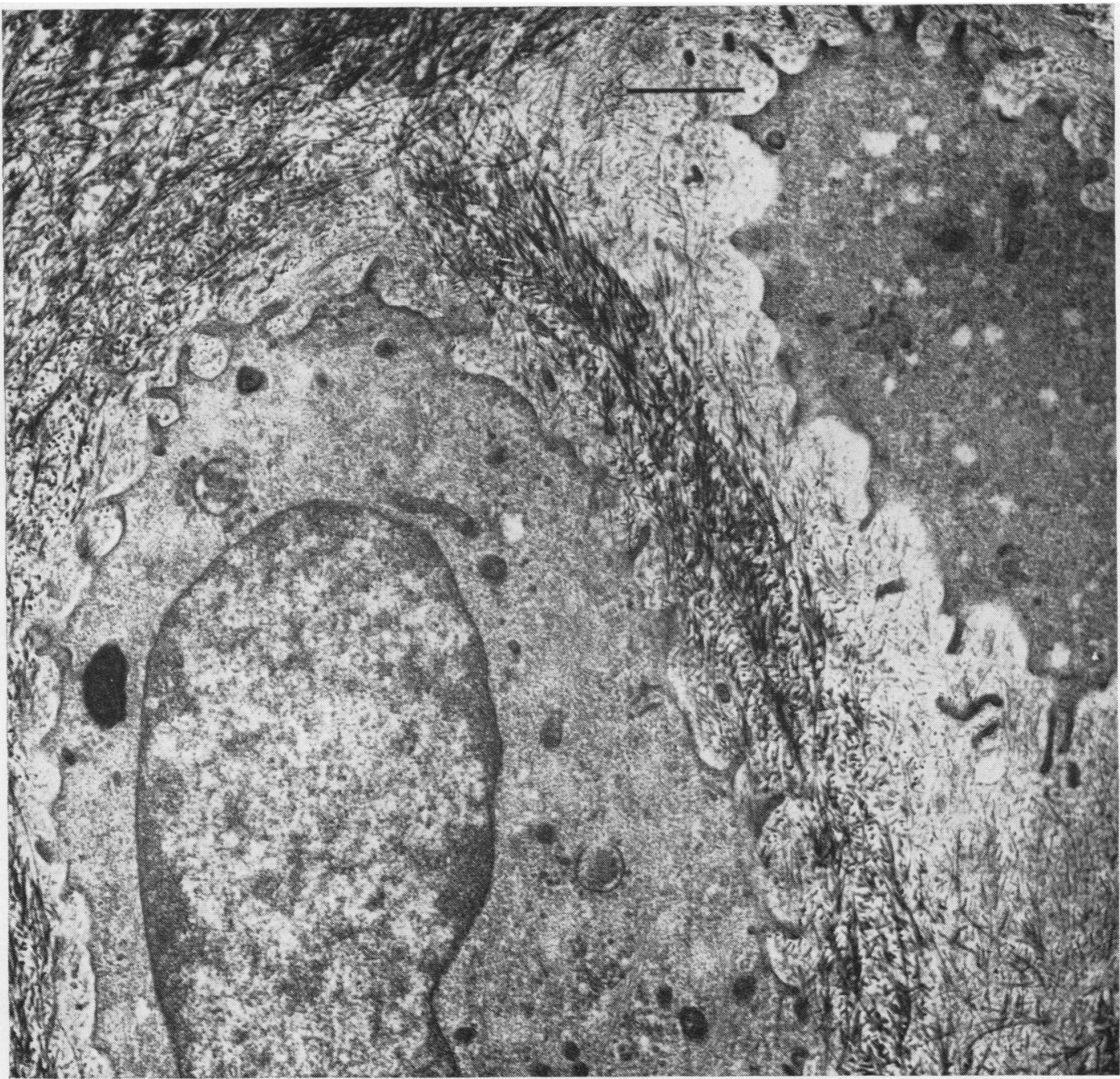

Fig. 4.-Pair of cells, of which the left is healthy, and the right degenerate, showing granular, vacuolated cytoplasm, from rabbit aged 1 year 2 months. Stained with uranyl acetate $(x 15,000)$. 


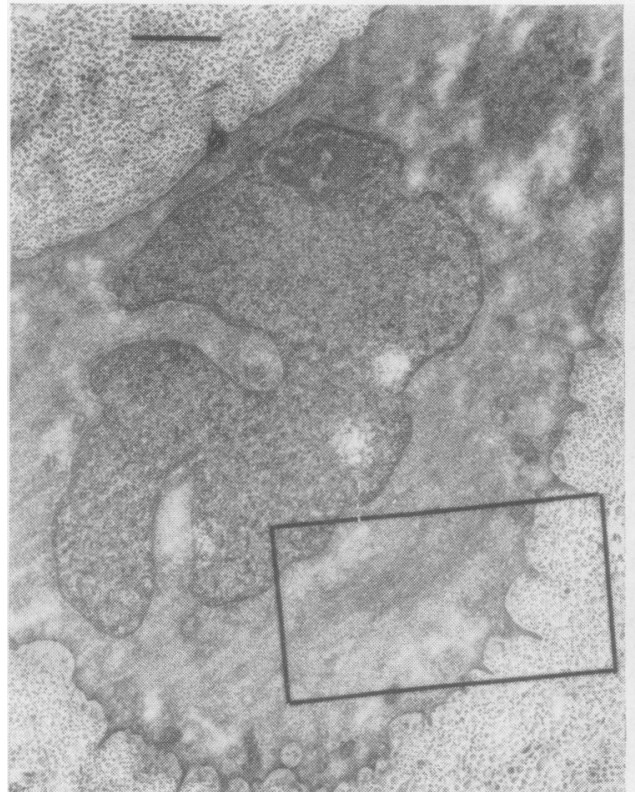

(a)

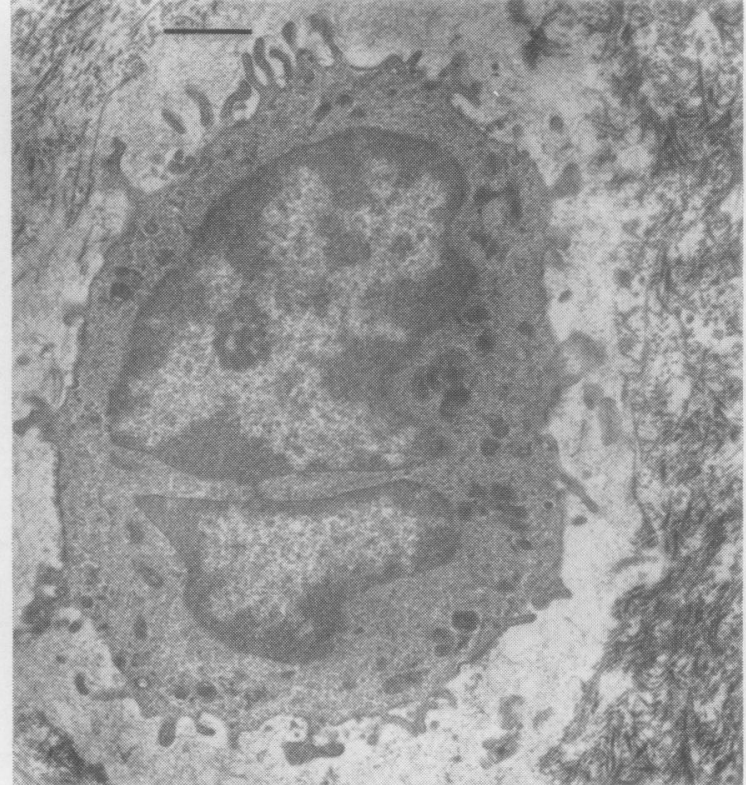

(b)

Fig. 5.-Two cells, showing irregular and partly divided nuclei. (a) Aged 3 years. (b) Age 1 year 2 months. Stained with uranyl acetate $(\times 9,000)$.

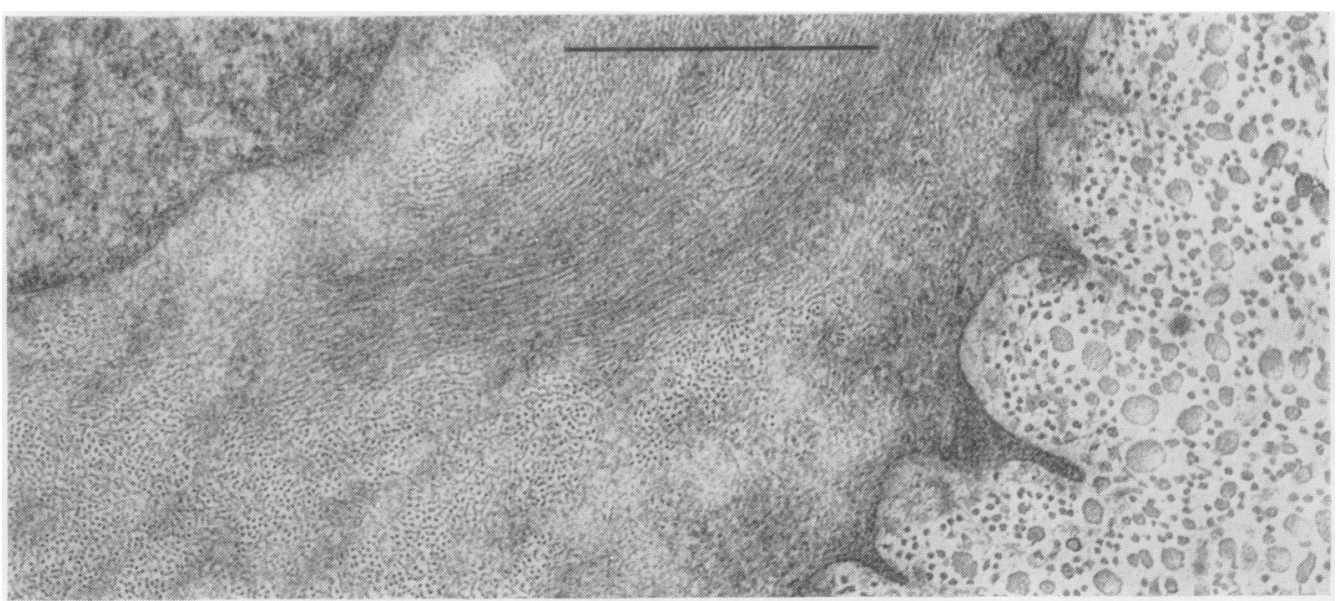

Fig. 6.-Part of Fig. 5(a) enlarged to show filaments in cytoplasm, cut longitudinally and transversely. Age 3 years. Stained with uranyl acetate $(\times 32,000)$. 


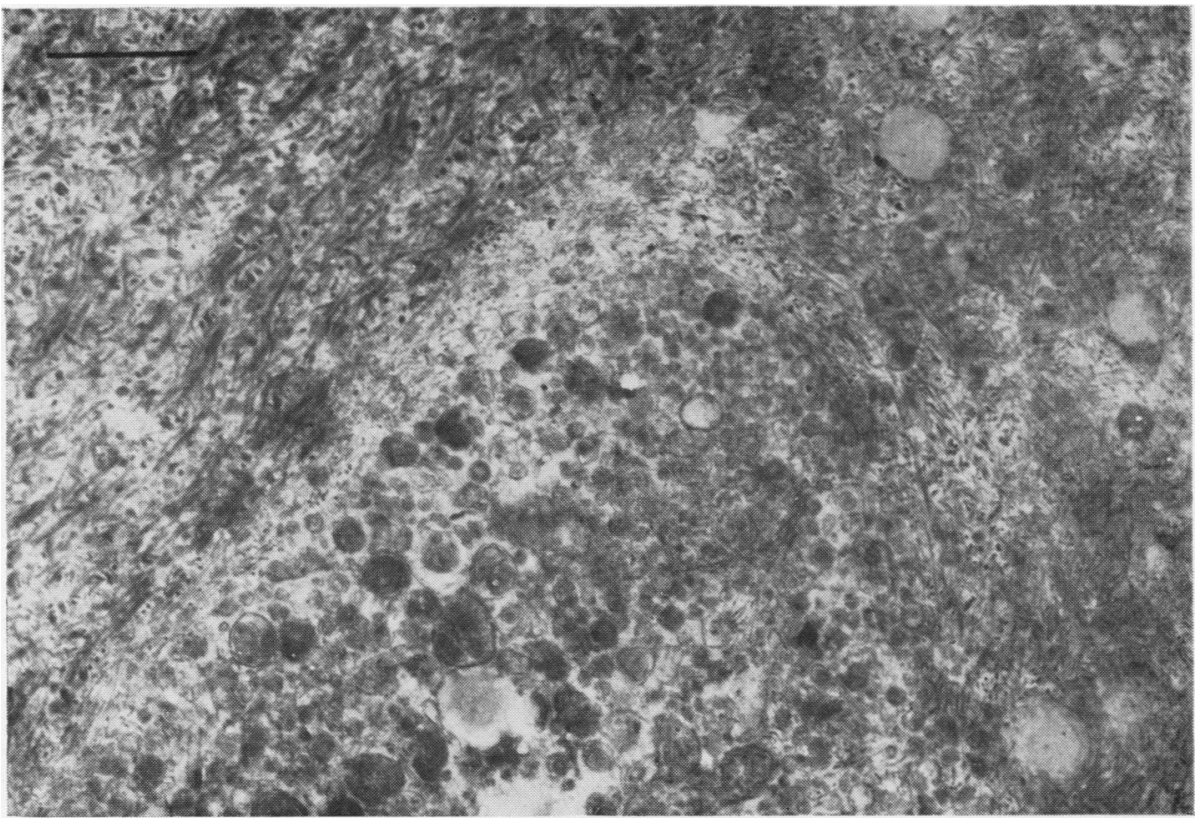

(a)

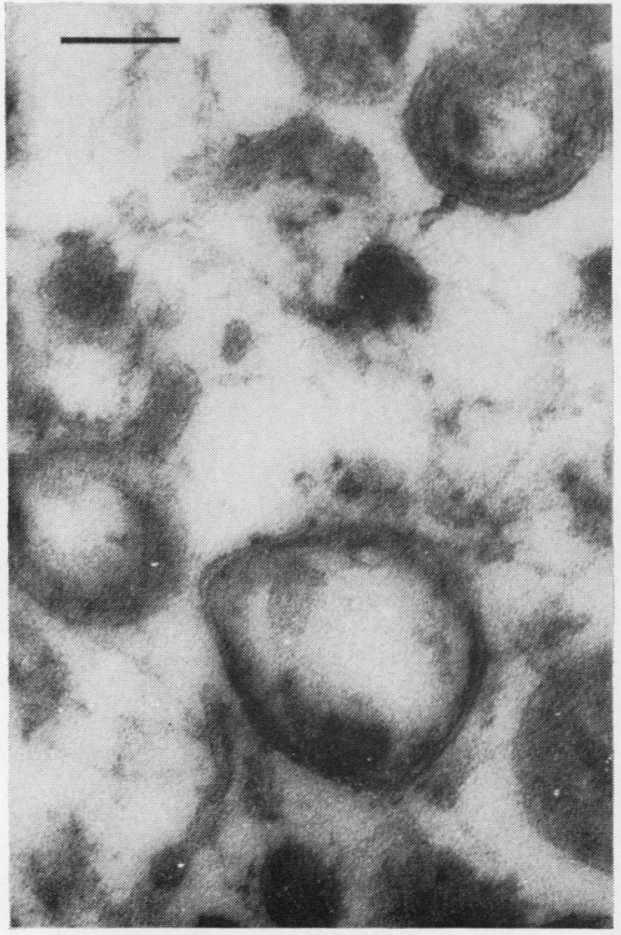

(b)

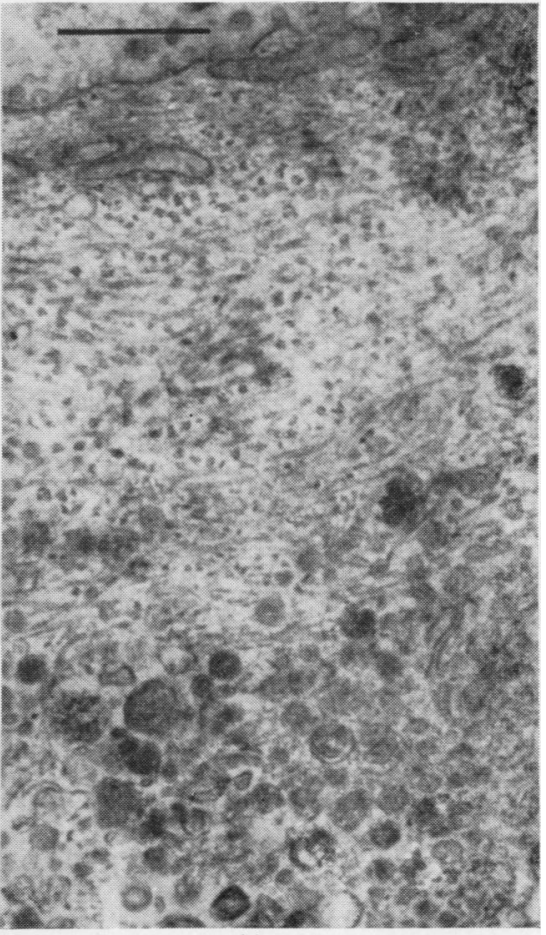

(c)

Fig. 7.-Remains of a cell seen as a mass of irregular bodies. (a) Age 3 years $(\times 15,000)$. (b) Myelin bodies. Age $4 \frac{1}{2}$ years $(\times 120,000)$. Line marker represents $0 \cdot 1 \mu$. (c) Masses of myelin bodies and cell remnants separated from wall of healthy cell (top) by fibres. Age $2 \frac{1}{2}$ years $(\times 15,000)$. All stained by uranyl acetate. 
thick fibres, up to $2,800 \AA$ in diameter. These exhibit $640 \AA$ banding and eight or nine obvious inter-period bands (Fig. 8). Some of these fibres lie in close proximity to degenerate cells and may appear to be enclosed within the cell substance. The boundary between adjacent large fibres is often indistinct.

There is evidence that the fibres in the matrix of the middle zone have an ordered arrangement. They run parallel to one another and to the surfaces of the cells. Around any particular cell they may be cut transversely (Fig. $5 a$ ) or longitudinally (Fig. $5 b$ ). This arrangement is more evident in the fine fibres immediately around the cells.

Deep Zone.-Here rosettes of apatite crystals are present in the regions of incomplete calcification, as in young material. Most of the cells show signs of degeneration, including loss of definition of nuclear and cell membranes and the disintegration of cytomembranes and other organelles, the remnants of which exhibit no tendency to be dispersed among the matrix fibres. The distended Golgi vacuoles and moats around the remnants of the cell, a form of degeneration observed in young cartilage, is uncommon in older material.

The calcification first surrounds the degenerating cells, but in those parts of the deep zone where calcification is more complete the rosettes invade the lacunae formerly occupied by the cells, producing a continuous mass of calcification. The spicules of apatite do not bear any constant relationship in their site of deposition or arrangement to the orientation of the collagen fibres of the matrix (Fig. 9, opposite).

The fibres in this zone have a diameter of 370 to $650 \AA$, and where cross-striation is visible the periodicity is $640 \AA$, with six or more inter-period bands.

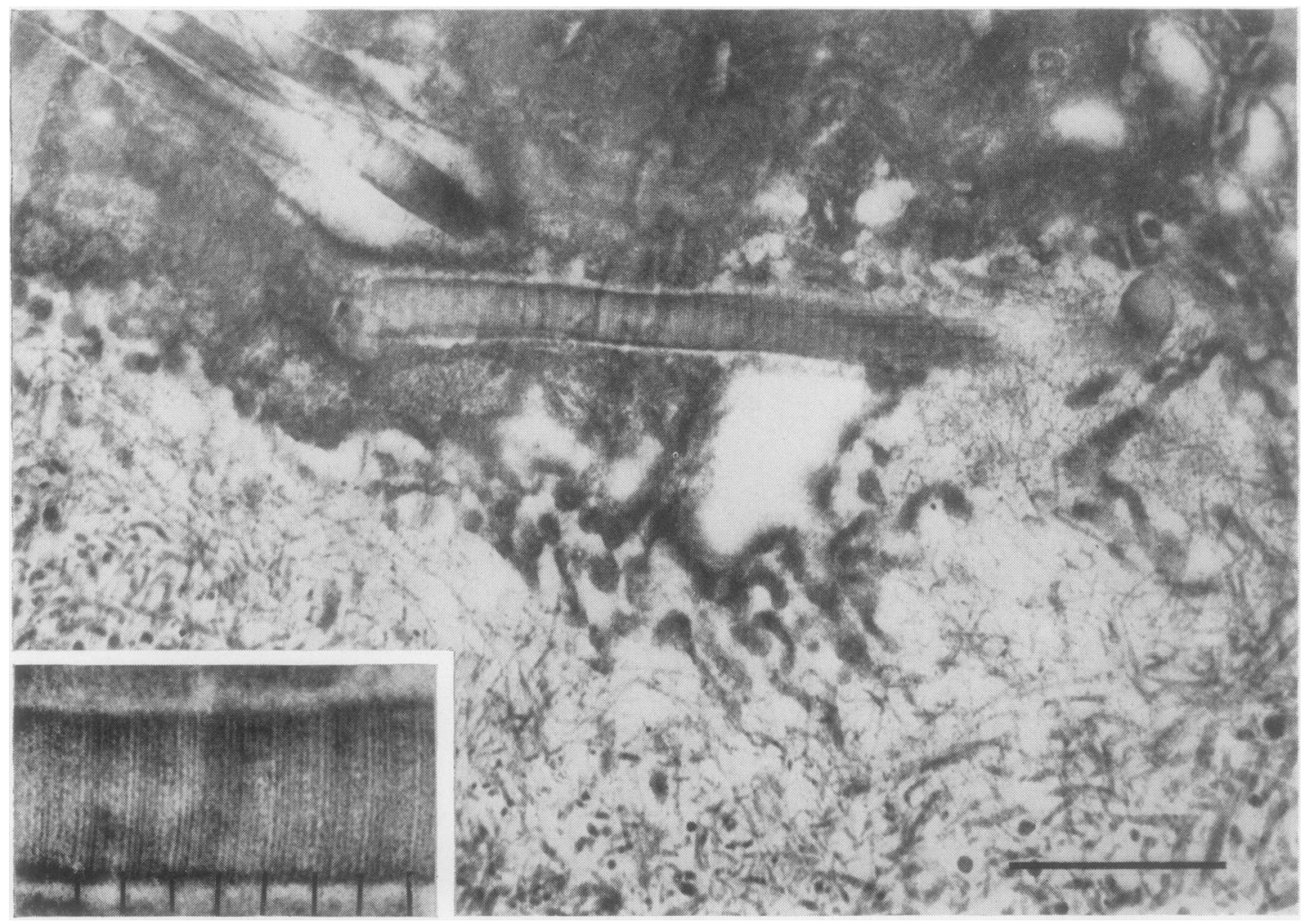

Fig. 8.-Part of a degenerate cell closely related to large fibre. Age $4 \frac{1}{2}$ years $(\times 25,000)$ Inset: Part of same fibre showing cross-banding $(\times 85,000)$. Stained with uranyl acetate. The $640 \AA$ bands are marked. 


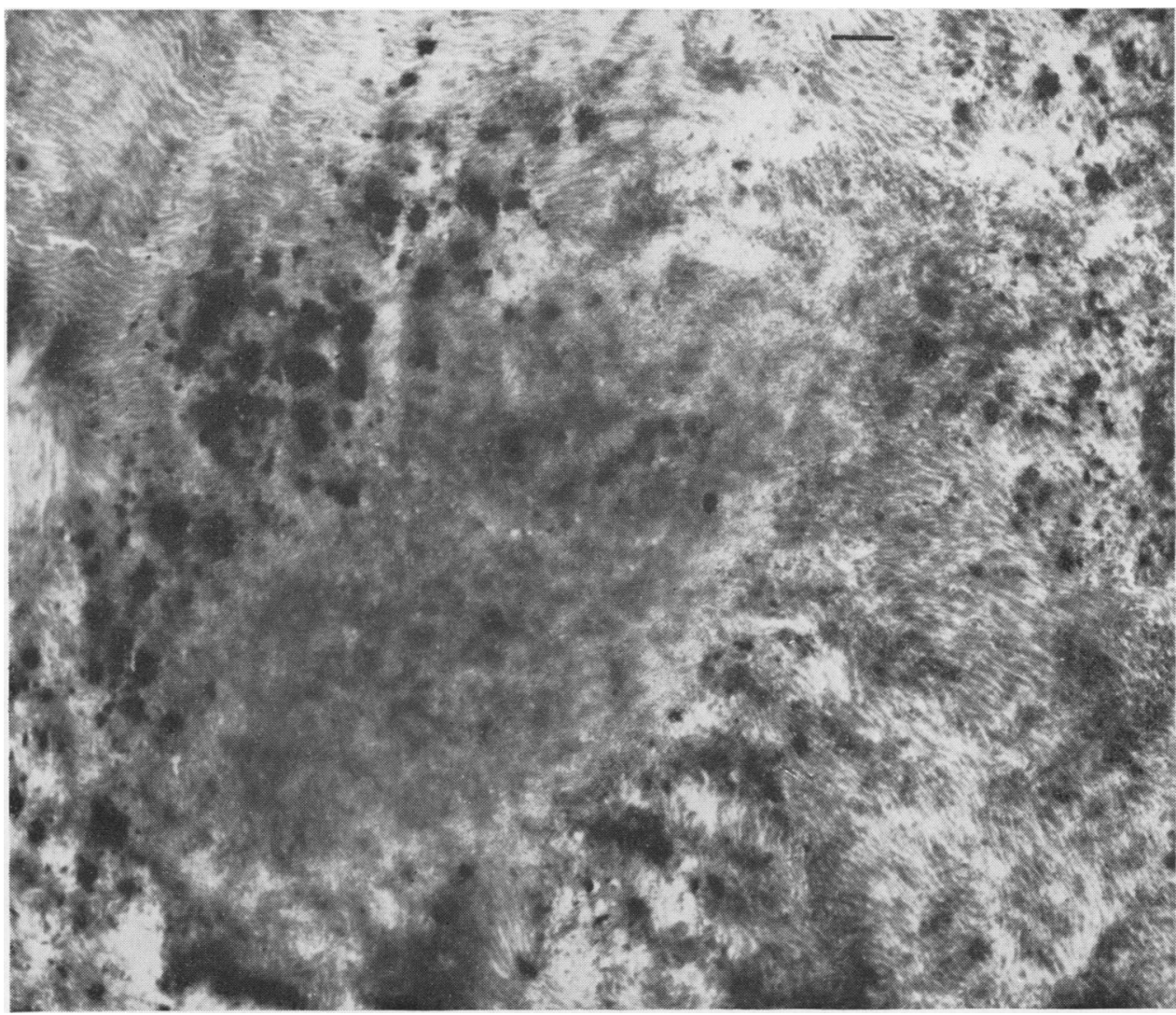

Fig. 9.- Region of deep zone probably occupied formerly by a cell, with rosettes of apatite nearby. Age 3 years. Stained with uranyl acetate $(\times 6,500)$.

\section{Discussion}

The increased irregularity of the articular surface in older animals must pose problems of lubrication. There is evidence that fluid film lubrication can obtain in synovial joints, at any rate in certain movements (Barnett and Cobbold, 1962) and an important factor is the thickness of the fluid film in relation to the prominences on the sliding surface (Dowson and Longfield, 1963). The fissures seen, though too minute to be visible by the light microscope, probably foreshadow the development of the coarse fissuration that is a feature of degenerative joint disease.

The reduction of cell density of rabbit cartilage with age conforms to observations made in other animals (Davies, 1961). It is sometimes assumed that this is due to shedding of surface cells into the joint cavity as a result of wear and tear. However, the cells in the superficial zone are by no means effete and, in the rabbit, the cell-free zone between them and the articular surface is increased; it is therefore unlikely that the cells are worn away at the surface. The granular masses seen in the matrix close to solitary healthy cells almost certainly represent the remnants of former partner cells. All stages can be seen, from cells exhibiting early degeneration to scattered amorphous granules dispersed among matrix fibres. The fate of the nucleus of a degenerate cell is not clear, because at an early stage the nucleoplasm loses its electron density and at the same time the nuclear membrane becomes irregular and difficult to see (Davies and others, 1962). It is possible that the nuclear material is then dispersed throughout the cytoplasm. The evidence of cell degeneration in all zones of the cartilage indicates that the lowered cell density 
with age can be explained in terms of death of many chondrocytes in situ, perhaps as a result of diminished permeability of the matrix to nutritive materials (Makowsky, 1948; Stockwell and Barnett, unpublished observations).

Stockwell (1963) has reported an increase in the phospholipid content of middle zone cells with age, possibly indicative of a degenerative process. The whorled myelin bodies seen in the present work closely resemble similar bodies, reported in other sites, that are known to be rich in phospholipid (Chou and Meek, 1958). The concomitant disappearance of mitochondria suggests that these phospholipid-containing bodies are derived from mitochondrial membranes.

No sign of amitosis has been observed in the present material. The evidence cited for this depends on the light microscope (Elliott, 1936); with the electron microscope it is confirmed that many cells of the middle zone have polymorphic nuclei but no subdivision of the cytoplasm has been seen. The lobation of the nuclei may be an indication of increasing cell age, as in the granulocytes of the blood, rather than of cellular proliferation. This view accords with that of Mankin (1963), whose autoradiographic studies produced no evidence of cell multiplication in articular cartilage of rabbits older than 6 months.

Even in healthy cells the cytomembranes are less prominent in older tissues, and no longer enclose electron-dense material between pairs of membranes. This may indicate diminution in secretion into the matrix and may be correlated with the known reduction in chondroitin sulphate concentration in older cartilage (Kaplan and Meyer, 1959).

The filaments observed in the cytoplasm resemble those reported in certain tumour cells and in phagocytes (Petris, Karlsbad, and Pernis, 1962). They have the same calibre as the short, peripherallysituated filaments reported in the rat within young chondrocytes from the femur and tibia (Godman and Porter, 1960). These authors postulate that the filaments may become "sloughed off" from the cell "to become the original elements of new matrix fibrils". The perinuclear orientation of the filaments described in the present material makes it unlikely that they represent collagen precursors. Their presence may indicate senility of the cell; similar filaments are present in Langhans' cells of full-term, but not of early, placentae (Lister, 1963).

The increasing coarseness of the general matrix fibres and their arrangement in bundles orientated perpendicular to the surface are features of ageing cartilage that are visible with the light microscope (Camosso and Marotti, 1962). The electronmicro- graphs indicate that the fine fibres sweep around the surfaces of the cells while the coarser fibres diverge widely but retain their general orientation. These coarse fibres are cut in considerable lengths, so they cannot exist in the helical form postulated for young cartilage fibres. The frequent presence of clear inter-period bands, between the main $640 \AA$ bands typical of collagen, is of interest, for in young material such banding was seen almost exclusively in fibres of the deep zone, close to regions of calcification.

Collagen fibres are known to become coarser with age (Harkness, 1961), but the large diameter of some of the fibres seen in older cartilage is exceptional; in man, comparable fibres have been reported only in the sclera of the eye (Schwarz, 1953). It is of interest that these large fibres are found within cartilage only in close proximity to cells showing evidence of senility.

The decreased electron density in the interfibrillar matrix between pairs of cells in older cartilage may indicate a lowered concentration of new protein synthesized by these cells; it is in keeping with the reduced electron density of material lying between pairs of cytomembranes.

In the deep zone the absence of cell columns perpendicular to the surface of the cartilage suggests that in the young animal these columns are associated with growth and are present in that part of the deep zone which is destined to ossify. The region of the femoral cartilage that is due to be converted into bone, deep to the true articular cartilage, is characterized by that type of degeneration in which there is distension of Golgi vacuoles, moat formation and the conversion of the cell into a spidery structure. This type of degeneration is rare in the present material. Mankin (1963) has emphasized that there is no clear boundary in young animals between the permanent articular cartilage and the underlying, temporary, hyaline cartilage of the epiphysis. Failure to appreciate this has led to a widespread belief that articular cartilage becomes thinner as it matures, by frictional wear and tear of the surface. Supporters of this view have stated that the cells at the surface are effete or dead; this assumption is not supported either by studies of cartilage repair (Calandruccio and Gilmer, 1962) or by the present investigations using the electron microscope.

\section{Summary}

The appearance under the light and electron microscopes of articular cartilage from rabbits ranging in age from 9 months to $6 \frac{1}{2}$ years is described. The findings are compared with those at 
2 to 3 months. The cell density decreases with age, especially near the surface, where flattened cells are seldom found. The surface itself becomes irregular and small fissures appear.

The cells in the middle zone are usually solitary. Their nuclei may be lobulated but this is an indication of ageing rather than amitotic division. In the cytoplasm, cytomembranes are rarely prominent, but bundles of filaments, each 90 to $100 \AA$ in diameter, are often seen.

There is evidence that many cells have died: all stages from early degeneration to scattered remnants of organelles are found, often as whorled myelin bodies which represent phospholipid deposits. The lowered cell density with age is due rather to this cell death in situ than to wearing away of the surface cells.

The matrix shows increased maturity of collagen fibres, which are no longer helically coiled and have a more ordered arrangement. Bundles of fine fibres sweep around the cells; coarse fibres diverge on each side of them. There are also some very large fibres, up to $2,800 \AA$ in diameter, in close association with surfaces of cells showing evidence of senility.

This work was carried out in the Electron Microscopy Unit set up at St. Thomas's Hospital Medical School by the Empire Rheumatism Council, to which we are greatly indebted. We are very grateful to Dr. R. A. Stockwell for the use of his histological material and for allowing us to reproduce two of his photographs as Fig. 1. Our thanks are due also to Prof. D. V. Davies for helpful advice and criticism and to Messrs. J. King, J. S. Fenton, and G. Maxwell for their invaluable technical assistance.

\section{REFERENCES}

Barnett, C. H., and Cobbold, A. F. (1962). J. Bone Jt Surg., 44B, 662.

Calandruccio, R. A., and Gilmer, W. S. (1962). Ibid., 44A, 431.

Camosso, M. E., and Marotti, G. (1962). Ibid., 44A, 699.

Chou, J. T. Y., and Meek, G. A. (1958). Quart. J. micr. Sci., 99, 279.

Davies, D. V. (1961). In "Structural Aspects of Ageing", ed. G. H. Bourne, p. 21. Pitman Medical Publishing, London.

-, Barnett, C. H., Cochrane, W., and Palfrey, A. J. (1962). Ann. rheum. Dis., 21, 11.

Dowson, D., and Longfield, M. D. (1963). Nature (Lond.), 197, 586.

Elliott, H. C. (1936). Amer. J. Anat., 58, 127.

Godman, G. C., and Porter, K. R. (1960). J. biophys. biochem. Cytol., 8, 719.

Harkness, R. D. (1961). Biol. Rev., 36, 399.

Kaplan, D., and Meyer, K. (1959). Nature (Lond.), 183, 1267.
Lister, U. M. (1963). J. Obstet. Gynaec. Brit. Emp., 70, 373.

Makowsky, L. (1948). Helv. chir. Acta, 15, 44.

Mankin, H. J. (1963). Anat. Rec., 145, 73.

Petris, S. de, Karlsbad, G., and Pernis, B. (1962). J. Ultrastructure Res., 7, 39.

Richardson, K. C., Jarett, L., and Finke, E. H. (1960). Stain Tech., 35, 313.

Schwarz, W. (1953). Z. Zellforsch., 38, 26.

Stockwell, R. A. (1963). J. Anat. (Lond.), 97, 146.

- and Barnett, C. H. (Unpublished observations.)

Altérations selon l'âge du cartilage articulaire du lapin

\section{RÉSUMÉ}

On décrit l'apparence, sous le microscope à lumière et électronique, du cartilage articulaire des lapins, agés de 9 mois à $6 \frac{1}{2}$ ans. On fait des comparaisons avec l'apparence aux âges de 2 à 3 mois. La densité cellulaire diminue avec l'âge, surtout près de la surface, où l'on trouve rarement des cellules aplaties. La surface elle même devient irrégulière et de petites fissures y apparaissent.

Les cellules de la zone moyenne sont habituellement solitaires. Leurs noyaux peuvent être lobulés mais ceci indique un vieillissement plutôt qu'une division amitotique. Dans le cytoplasme les cytomembranes sont rarement en évidence, mais des faisceaux de filaments, chacun de 90 à $100 \AA$ de diamètre, se voient souvent.

On trouve des signes indiquant que beaucoup de cellules avaient péri: dès le stade de dégénérescence aux vestiges dispersés d'organelles, souvent sous forme de corpuscles volutés de myéline représentant des dépôts phospholipides. La densité cellulaire diminuée avec l'âge est due plutôt à cette mort cellulaire in situ qu'à l'usure des cellules de surface.

La matrice montre une maturité augmentée des fibres collagènes, qui ne forment plus de rouleaux en hélice et s'arrangent d'une manière plus ordonnée. Des faisceaux de fines fibres parcourent les cellules; de plus épaisses fibres divergent de chaque coté. Il y a aussi de très grosses fibres, jusqu'à $2.800 \AA$ de diamètre, étroitement associées aux surfaces des cellules portant des signes de sénilité.

Alteraciones del cartílago articular de conejo con la edad

\section{SUMARIO}

Se describe la apariencia, bajo el microscopio luminoso y electrónico, del cartílago articular de conejos, de 9 meses a $6 \frac{1}{2}$ años de edad. Se hacen comparaciones con la apariencia a las edades de 2 a 3 meses. La densidad celular disminuye con la edad, particularmente cerca de la superficie, donde las células aplastadas se ven raramente. La superficie misma se vuelve irregulary se cubre de pequeñas rajas.

Las células de la zona media son generalmente solitarias. Sus núcleos pueden ser lobulados pero esto no indica que se dividen por amitosis sino, más bien, que envejecen. En el citoplasma las citomembranas se evidencian raramente, pero haces de filamentos, de diametro de 90 a $100 \AA$, se ven frecuentemente.

Se notan indicios de muerte de muchas células, desde la etapa de degeneración hasta los vestigios dispersados de organitas, a menudo en forma de cuerpos espirales 
de mielina, que representan depósitos fosfolípidos. La densidad celular disminuida con la edad se debe más bien a esta muerte celular in situ que al desgaste de las células superficiales.

La matriz acusa una madurez acentuada de las células colágenas, que ya no forman rollos helicoides y que se

disponen de una manera más ordenada. Haces de fibras finas atraviesan las células; fibras más espesas divergen de cada lado. Hay también fibras muy gruesas, hasta $2.800 \AA$ de diametro, estrechamente asociadas con superficies de células que muestran evidencia de senilidad. 